\title{
Sperm Characteristics of Tiger Grouper (Epinephelus fuscoguttatus), Comouflage Grouper (Epinephelus polyphekadion) and Giant Grouper (Epinephelus lanceolotus) in Controled tanks
}

\author{
${ }^{1,2}$ Apri I. Supii, ${ }^{2}$ Diana Arifati, ${ }^{2}$ Maheno Sri Widodo and ${ }^{2}$ YuniKilawati
}

${ }^{1}$ Research and Development Institute for Mariculture (RDIM) Gondol-Bali, Indonesia

${ }^{2}$ Faculty of Fisheries and Marine Science, Brawijaya University, Indonesia

Correspondence Author: Apri I. Supii, Research and Development Institute for Mariculture (RDIM) Gondol-Bali, Indonesia E-mail: aprisupii@yahoo.co.id

Received date: April 2018, Accepted date: 28 July 2018, Online date: 5 August 2018

Copyright: (C) 2018 Apri I. Supii, et al., This is an open-access article distributed under the terms of the Creative Commons Attribution License, which permits unrestricted use, distribution, and reproduction in any medium, provided the original author and source are credited.

\begin{abstract}
The research object is sperm of tiger grouper (Epinephelus fuscoguttatus), camouflage grouper (Epinephelus polyphekadion) and giant grouper (Epinephelus lanceolotus). They are an important commodity used for hybridization in Asian. The research purpose is to know the sperm characteristics of the groupers. Sperm samples were obtained from selected mature male gonads. Parameters to determine the sperm characteristics are morphology, sperm plasma composition and the functional group analysis based on FTIR test. Morphological observations show that sperm of giant grouper (Epinephelus lanceolatus) has the largest head size. Six ion components observed in sperm plasma fishes were calcium, carbon, chlorine, oxygen, phosphorus and sodium. However, percentage of carbon and sodium ions in plasma sperm of camouflage grouper (Epinephelus polyphekadion) is unknown or nil. Information from the FTIR test shows that the three sperm tested have a functional group profile that tend same with wave number range of $667-3423 / \mathrm{cm}$.
\end{abstract}

Key words: grouper, sperm, head length, electrolyte, functional form

\section{INTRODUCTION}

One successful determinant of fish reproduction is the quality of spermatozoa (Mekkawy and Osman, 2006). Spermatozoa acts as a haploid genetic material distribution agent in process of egg fertilization to create new individuals (Cosson, et al., 2008). Grouper is an important commodity for Asia, the one kind is camouflage grouper (E polyphekadion) as a new export fishery product for Indonesia (Jayadi, et al., 2017). In addition, Indonesia became the second tiger grouper (E fuscoguttatus) producer in ASEAN region with seed production rate of 1-5 million per month (Sugama, 2014; Yulianto, et al., 2015; Pahlevi, 2016). The increase of grouper production in Indonesia has taken place since 2001 and currently become the group's main producer of Life Reef Food Fishes (LRFF) trading in Asia (Palm, et al., 2015). It includes giant grouper (E lanceolatus) cultivated on a small scale since 2003 (Bunting, 2013 ). Therefore, information on sperm characteristics of fish grouper in Gondol, Bali is reference important to enrich the purposes, future cultivation techniques development and comparison for other commodities.

Common parameters used to compare sperm characteristics among fish are morphology and sperm plasma ion content (Alavi, et al., 2011). Therefore, this study to determine the sperm characteristics of morphology, sperm plasma composition and functional group analysis based on FTIR test.

\section{Sperm collection:}

\section{METHODS AND MATERIALS}

The selected fishes are adapted for one month in a concrete tank with 5x5x1.5 msize, at a water circulation system of $300 \%$ per day. Mature male gonad is characterized by a pale white discharge when the stomach is pressed. Sperm collection is done by moving the fishes from the reservoir using a net scoop into a tray coated with a wet cloth. The urogenital part is wiped with tissue to avoid seawater contamination. The fishes stomachare pressed slowly at direction from below the lateral linea (above the abdominal fins) toward the genital pit and the sperm taken with a $1 \mathrm{ml}$ plastic spuit.

\section{Observation of Sperm morphology:}

The fishes sperm morphology were observed by scanning electron microscope and fixation techniques (Verma et al.,2009). The preparation was done by modified Karnovsky solution to mix $0.2 \mathrm{M}$ phosphate and 40 grams of paranormaldehide into $960 \mathrm{ml}$ of aquabides and $40 \mathrm{ml}$ glutaraldehideat $25 \%$ concentration, added by $0.1 \mathrm{M}$ sodium phosphate buffer solution to maintain $7.4 \mathrm{pH}$. Fixation was done for 3 hours at $4^{\circ} \mathrm{C}$, rinsed by buffer solution 3 times with aquabides for 15 minutes. The sample is dried and placed into a cup for $20 \mathrm{~nm}$ palladium gold plated (SEM Leo 435 UP). The observation was done by SEM6200 Series LabGeni microscope.

\section{Observation of Plasma Sperm Composition:}

The sperm samples were fed into Eppendorf tubes with centrifugation at $1000 \mathrm{~g}$ for 10 . Supernatant was obtained after repeating this step three times. Samples were analyzed by Inductive coupled plasma emission spectroscopy (Perkin Elmer Optima, 3100RL), based on modified method of Widyatmoko (2004). All glassware was rinsed with $1 \% \mathrm{HNO} 3$ solution to remove dust and avoid contamination. A total of $0.1 \mathrm{ml}$ sample was added with $1 \mathrm{ml}$ of water, $1 \mathrm{ml}$ of water regia and $6 \mathrm{ml}$ of $\mathrm{HF}$ concentration of $40 \%$. The mixture was moved into the graphite glass, then inserted into autoclave and heat for $90 \mathrm{minutes}$ at $110{ }^{\circ} \mathrm{C}$. The sample was cooled by putting it into $150 \mathrm{ml}$ PTX glass containing $20 \mathrm{ml}$ of water and 2.8 gr of $\mathrm{H} 3 \mathrm{BO} 3$ crystals, stirred by magnetic stirrer for 5 minutes. The 25 
Citation: Apri I. Supii, et al., Sperm Characteristics of Tiger Grouper (Epinephelus fuscoguttatus), Comouflage Grouper (Epinephelus polyphekadion) and Giant Grouper (Epinephelus lanceolotus) in Controled tanks. Australian Journal of Basic and Applied Sciences, 12(8): 1-5. DOI: 10.22587/ajbas.2018.12.8.1

$\mathrm{ml}$ solution was taken and poured into $200 \mathrm{ml}$ capacity measuring tab. Addition $2 \mathrm{ml}$ with $10 \% \mathrm{Cs}$ solution is used to remove interference and destruction in microwave.

\section{FTIR Test:}

Fourier Transform Infra Red Analysis for sperm test refers to modification of Schütze (2015) research. The $1 \mathrm{ml}$ sample was moved into microtube and centrifuged with speed $3000 \mathrm{rpm}$ for 2 minutes. The supernatant was removed. The obtained pellet was added by $2 \mu \mathrm{lPBS}$. The sample was placed intoattenuated total reflection (ATR) sample holder. The sample was treated for 10 minutes with automatic evaporation of $\mathrm{CO}_{2} / \mathrm{H}_{2} \mathrm{O}$, then put into infrared ray pathway. The spectrum was measured by FTIR spectrometer at wavelength $400-4000 \mathrm{~cm}^{-1}$. The Perkin-Elmer software (PerkinElmer, Norwalk, CT, USA), and Omnic (ThermoNicolet, Madison, WI, USA) were used to analyze and display infrared spectrum. Observe the chart peak and save the image.

Research Results:

Sperm morphology:

Observation of sperm morphology showed that A, B and C fishes had round head shape. The A fishes (E fuscoguttatus) has a sperm-length range of 1.62$1.77 \mu \mathrm{m}$. The B fishes (E polyphekadion) has a sperm length range of I.55-1.67 $\mu \mathrm{m}$. Documentation of SEM microscope shows the test sperm C fishes $(E$ lanceolotus) have the largest head length size of 2.03-2,23um (Figure 1).Each type of fishes getsixobservationsand the average value was calculated. The sperm head of E polyphekadion were $1.61 \mu \mathrm{m} ; 1.55 \mu \mathrm{m} ; 1.58 \mu \mathrm{m} ; 1.64 \mu \mathrm{m} ; 1.62 \mu \mathrm{m}$ and $1.66 \mu \mathrm{m}$. The sperm head of E fuscoguttatus samples were longer at $1.62 \mu \mathrm{m}$; $1.77 \mu \mathrm{m} ; 1.75 \mu \mathrm{m} ; 1.66 \mu \mathrm{m} ; 1.71 \mu \mathrm{m}$ and $1.65 \mu \mathrm{m}$. The sperm head of E lanceolotus were $2.03 \mu \mathrm{m}$ and followed by $2.18 \mu \mathrm{m} ; 2.21 \mu \mathrm{m} ; 2.09 \mu \mathrm{m} ; 2.14 \mu \mathrm{m}$ to 2.23 $\mu \mathrm{m}$. These were the largest sperm based on morphological appearance and head measurement. The analysis shows significant differences $(\mathrm{P}<0.05)$ in each sperm head test,as shown in Table 1 and figure 1.

Table 1: Length Measurement of Fishes Sperm Head.

\begin{tabular}{|l|l|}
\hline Fishes type & Head length average $(\boldsymbol{\mu m})$ \\
\hline Epinephelus fuscoguttatus & $1.69 \pm 0.060^{\mathrm{b}}$ \\
\hline Epinephelus polyphekadion & $1.61 \pm 0.040^{\mathrm{a}}$ \\
\hline Epinephelus lanceolotus & $2.14 \pm 0.081^{\mathrm{c}}$ \\
\hline
\end{tabular}

The data was the mean and standard deviation $(\mathrm{n}=6)$. There were significant differences $(\mathrm{P}<0.05)$, as shown in figure 1 below.

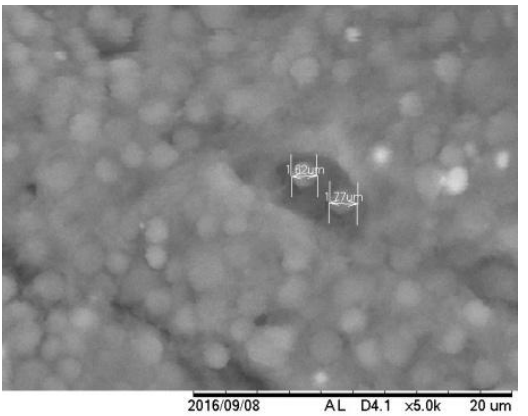

$\operatorname{macan} \mathrm{F}$

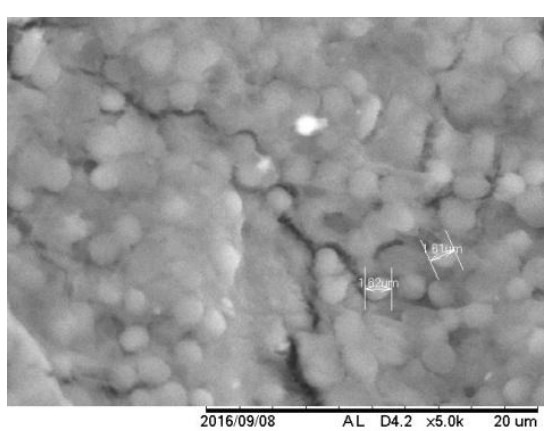

Epinephelus polyphekadion ;

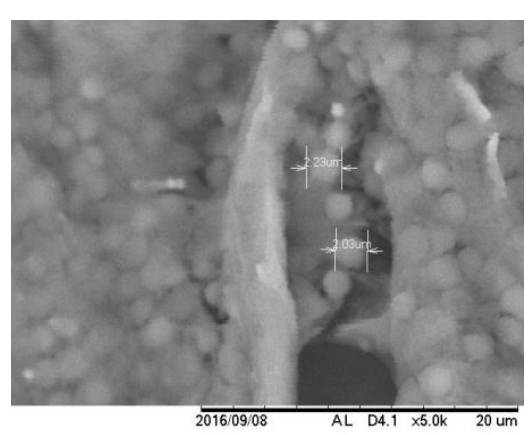

kertang

Epinephelus lanceolotus

Fig. 1: The Morphological Appearance of Fishes Spermwith SEM Microscope at 5000x magnification.

\section{Composition of Sperm Plasma:}

The experiments results for on each fish can be seen in Table 2. The plasma sperm of tiger groupers contain $57.83 \mathrm{mM}$ carbon, $33.63 \mathrm{mM}$ oxygen, $2.39 \mathrm{mM}$ sodium or sodium, $2.4 \mathrm{mM}$ potassium, $1.59 \mathrm{mM}$ chlorine and $2.16 \mathrm{mM}$ calcium. It is followed by a medium-sized group of giant grouper contain $40.7 \mathrm{mM}$ of carbon, $48.06 \mathrm{mM}$ oxygen, $3.42 \mathrm{mM}$ sodium or sodium, $2.33 \mathrm{mM}$ potassium, $3.42 \mathrm{mM}$ chlorine and $2.07 \mathrm{mM}$ calcium. The sperm plasma of camouflage grouper contain no value of carbon and sodium. The composition was only $67.56 \mathrm{mM}$ oxygen, $8.98 \mathrm{mM}$ potassium, $8.26 \mathrm{mM}$ chlorine and $15.19 \mathrm{mM}$ calcium.

Table 2: Sperm Composition of Plasma Test.

\begin{tabular}{|c|c|c|c|c|c|c|c|c|c|}
\hline \multirow{2}{*}{ Elements } & \multicolumn{3}{|l|}{ Weight \% } & \multicolumn{3}{|c|}{ Weight \% o } & \multicolumn{3}{|c|}{ Atomic \% } \\
\hline & $\begin{array}{l}\text { Tiger } \\
\text { Grouper }\end{array}$ & $\begin{array}{l}\text { Giant } \\
\text { Grouper }\end{array}$ & $\begin{array}{l}\text { Comouflage } \\
\text { Grouper }\end{array}$ & $\begin{array}{l}\text { Tiger } \\
\text { Grouper }\end{array}$ & $\begin{array}{c}\text { Giant } \\
\text { Grouper }\end{array}$ & $\begin{array}{l}\text { Comou } \\
\text { flage } \\
\text { Grouper }\end{array}$ & $\begin{array}{l}\text { Tiger } \\
\text { Grouper }\end{array}$ & $\begin{array}{c}\text { Giant } \\
\text { Grouper }\end{array}$ & $\begin{array}{l}\text { Comouflage } \\
\text { Grouper }\end{array}$ \\
\hline Carbon & 46.154 & 30.315 & - & 3.911 & 8.928 & - & 57.827 & 40.704 & - \\
\hline Oxygen & 35.754 & 47.674 & 47.822 & 3.265 & 6.568 & 3.543 & 33.630 & 48.056 & 67.575 \\
\hline Sodium & 3.658 & 4.875 & - & 0.603 & 1.094 & - & 2.394 & 3.420 & - \\
\hline Potassium & 4.946 & 4.474 & 12.301 & 0.625 & 0.966 & 1.490 & 2.403 & 2.329 & 8.978 \\
\hline Chlorine & 3.745 & 7.525 & 12.950 & 0.522 & 1.324 & 1.665 & 1.589 & 3.423 & 8.258 \\
\hline Calcium & 5.743 & 5.138 & 26.928 & 0.678 & 1.035 & 2.401 & 2.156 & 2.067 & 15.189 \\
\hline
\end{tabular}

Group Function of Sperm:

The mass spectrum of tiger grouper (Epinephelus fuscoguttatus), giant grouper (Epinephelus lanceolotus)) and camouflage grouper(Epinephelus polyphekadion) are shown Figure 2. The infrared absorption tape have certain character patterns. Details of each tape wavelength can be seen in Table 3 .

The three sperm tests have similar infrared spectrum profile. The first spectrum detection was occurred in hydrogen vibration region with frequency 3423.41 $\mathrm{cm}^{-1}$ (E polyphekadion), $3425.34 \mathrm{~cm}^{-1}$, (E fuscoguttatus) and $3456.20 \mathrm{~cm}^{-1}$ (E lanceolatus). These are categorized as acidic compounds within OH groups. The 
second spectrum also located at hydrogen vibration region, the alkane compound have frequency of $2960.53 \mathrm{~cm}^{-1}(E$ fuscoguttatus $)$ and $2962.46 \mathrm{~cm}^{-1}(E$ polyphekadion), and containing the strand stratum $-\mathrm{CH}_{3}\left(\mathrm{sp}^{3}\right)$ group(E lanceolatus). The third spectrum has alkane compound with cluster $-\mathrm{CH}_{2}(\mathrm{sp} 3)$ stretched, present at $2854.45 \mathrm{~cm}^{-1}$ (E lanceolatus) and $2856.38 \mathrm{~cm}^{-1}$ for (E fuscoguttatus) and $E$ polyphekadion. The forth spectrum has alkene compound in fingerprint $1650.95 \mathrm{~cm}^{-1}$ for $E$ fuscoguttatus and $E$ polyphekadion and Elanceolatus with a frequency of $1652.88 \mathrm{~cm}^{-1}$ with $-\mathrm{C}=\mathrm{C}$ group (non strand conjugate bond). The fifth spectrum was detected at $1454.23 \mathrm{~cm}^{-1}$ (E lanceolatus) and $1456.16 \mathrm{~cm}^{-1}$ (E fuscoguttatus), (E polyphekadion) and categorized as other compounds with cluster content $-\mathrm{CH}_{2}$ bend. The sixth Spectrum has frequency of $1396.37 \mathrm{~cm}^{-1}$ (E fuscoguttatus), (E polyphekadion) and $1398.30 \mathrm{~cm}^{-1}$ (E lanceolatus), described as another compound with $-\mathrm{C}(\mathrm{CH} 3)_{2}$ bend group or called dimethyl germinal. The seventh spectrum has frequencies of $1228.57 \mathrm{~cm}^{-1}$ (E fuscoguttatus), (E lanceolatus) and $1230.50 \mathrm{~cm}^{-1}$ (E polyphekadion) and eighth spectrum of all three fishes has $1087 \mathrm{~cm}^{-1}$, it is described as esters. These two spectra sequentially contain C-O-stretching group and then C-O alcohol 20. Finally, ninth spectrum is described as another compound with a cyclic group = C-H band (OOP) content. Each sample of this spectrum has three frequencies: $968.20,892.98,649.97 \mathrm{~cm}^{-1}$ for E fuscoguttatus and $970.13,891.05,563.18 \mathrm{~cm}^{-1}$ for E lanceolatus and $970.13 \mathrm{~cm}^{-1}, 891.05 \mathrm{~cm}^{-1}$ and $667.32 \mathrm{~cm}^{-1}$ for E lanceolatus. Table 3 shows the FTIR result for fishes sperm

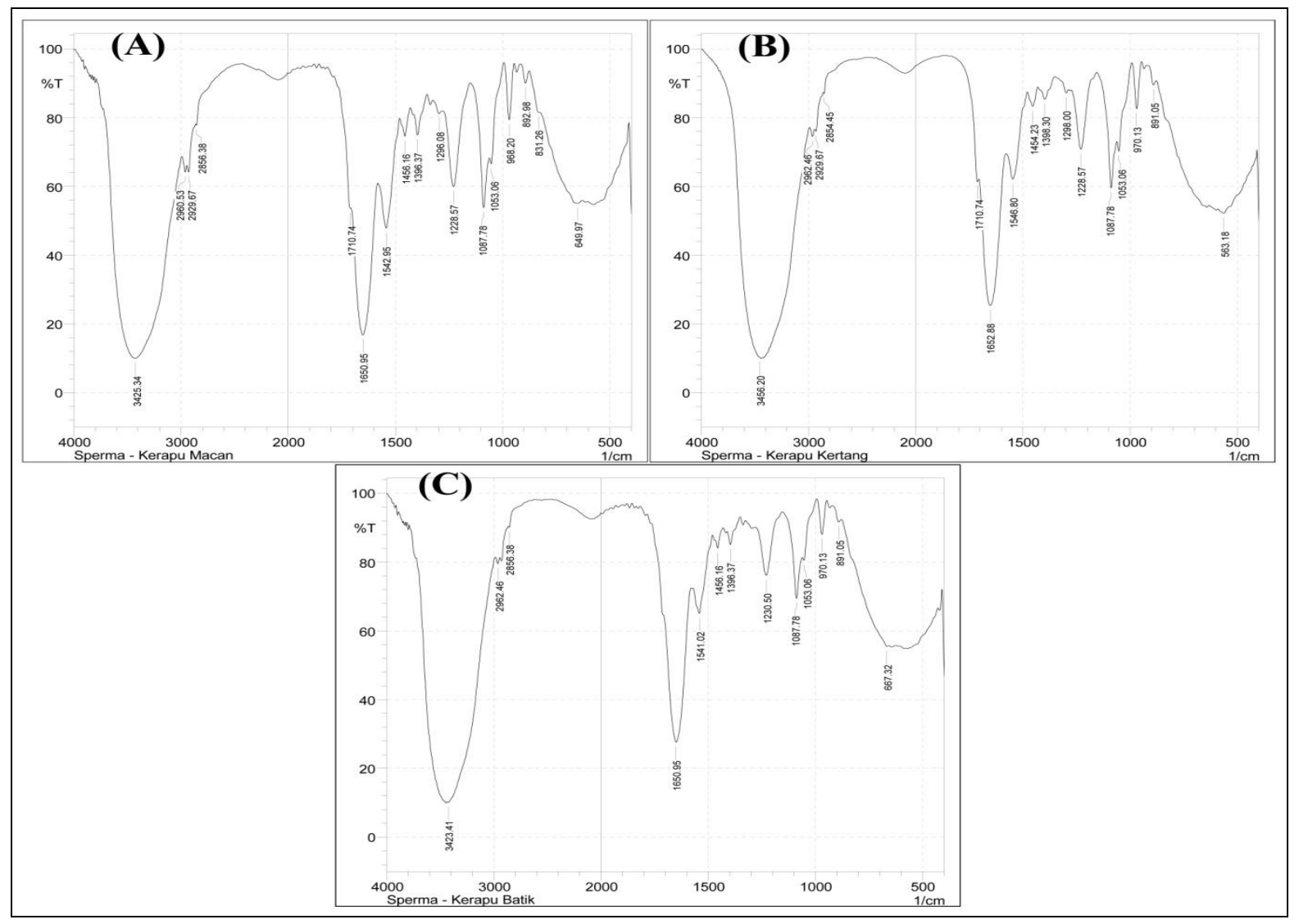

Fig. 2: Sperm Ftir Test Results for (A) Epinephelus fuscoguttatus, (B) Epinephelus lanceolotus and (C) Epinephelus polyphekadion.

Table 3: FTIR results forFishes Sperm.

\begin{tabular}{|l|l|l|l|}
\hline No & Wave $\left(\mathbf{C m}^{-1}\right)$ & Range (Socrates, 1994) & Vibration Type \\
\hline 1 & 3423 & $3550-3230$ & OH stretch \\
\hline 2 & 2962 & $3000-2800$ & $-\mathrm{CH}_{3}\left(\mathrm{sp}^{3}\right)$ stretch \\
\hline 3 & 2856 & $2870-2840$ & $-\mathrm{CH}_{2}-\left(\mathrm{sp}^{3}\right)$ stretch \\
\hline 4 & 1650 and 1541 & $1680-1620$ & $-\mathrm{C}=\mathrm{C}$ stretch non conjugation \\
\hline 5 & 1456 & $1480-1440$ & $-\mathrm{CH}_{2}$ bend \\
\hline 6 & 1396 & $1385-1365$ & $-\mathrm{C}\left(\mathrm{CH}_{3}\right)_{2}$ bend \\
& & & or germinal dimethyl \\
\hline 7 & 1230 & $1300-1200$ & $-\mathrm{C}-\mathrm{O}$ stretch \\
\hline 8 & 1087 & $1125-1085$ & $\mathrm{C}-\mathrm{O}$ alcohol $2^{0}$ \\
\hline 9 & $970,891,667$ & $995-650$ & $=\mathrm{C}-\mathrm{H}$ cyclical band $(\mathrm{OOP})$ \\
\hline
\end{tabular}

\section{Discussion:}

Same as previous studies of longtooth grouper (Epinephelus bruneus) and giant grouper (E lanceolatus), the fishes spermof this study also show round heads (Kim et al., 2013; Tian, et al., 2015). Thelength is shorter than Cod fishes sperm heads, ranging from 2.6 to $3.6 \mu \mathrm{m}$ (Tuset, et al., 2008). Comouflage grouper has an average sperm head length of $1.61 \mu \mathrm{m}$. Tiger grouper fishes has an average sperm head length of $1.69 \mu \mathrm{m}$. The giant grouper has an average sperm head length of $2.14 \mu \mathrm{m}$. Each sperm significantly has a different head length. Differences size of sperm head can relatesto morphology of egg micro filter hole of each species 
Citation: Apri I. Supii, et al., Sperm Characteristics of Tiger Grouper (Epinephelus fuscoguttatus), Comouflage Grouper (Epinephelus polyphekadion) and Giant Grouper (Epinephelus lanceolotus) in Controled tanks. Australian Journal of Basic and Applied Sciences, 12(8): 1-5. DOI: 10.22587/ajbas.2018.12.8.1

as the main door to accept the sperm in fertilization process (Rurangwa, 2004). In other words, generally the size of a species sperm is neither too large nor small from the egg-micropole hole of female parent.

The fishes must go to long path to get into microfilehole. It starts from active preparation of parent body into the waters until the competition to reach the egg. Therefore, naturally the existence of sperm in parent body is sustained by two main components, namely organic and inorganic. The organic materials content of proteins and glucose plays a role in formation of ATP for sperm survival (Hajirezae, et al., 2010). The ananhydallic material content from ions such as Na,$+ \mathrm{K}$ + and $\mathrm{Cl}_{-}$ions in spermplasma plays a role to maintain isotonic conditions to prevent early sperm movement (Bozkurt, et al., 2011). Inorganic electrolytes in sperm plasma fishes are carbon, oxygen sodium, potassium, chlorine and calcium. Carbon is most abundant in sperm plasma of tiger grouper and is not found in comouflage grouper. Among the three fishes, comouflage grouper has the highest oxygen content. The largest sodium or sodium is owned by plasma sperm of giant grouper and followed by tiger grouper. This value is similarto sodium range in Walleye fishes (Sander vitreus) 2.4-3.8 mM (Kestemont, et al., 2015). It is smaller than the rainbow trout (Salmogardineri) of $127 \mathrm{mM}$ (Morisawa, et al., 1983). The third potassium content of the fishes is above black seabream (Spondyliosomacantharus) and puffer (Arothronmeleagris) of 2-5.3 mM. However, this value is below the saltwater fishes ofAtlantic salmon (Salmosalar) of 22$27.5 \mathrm{mM}$, especially goldfishes (Carassiusauratus) of freshwater fishes of 55-70.2 mM (Suquet, et al., 1994). The content of chlorine tiger grouper and giantgrouper are lower than Walleye (Sander vitreus) freshwater fishes ranging from 4.3-4.7 mM.The value of comouflage grouper is larger than walleye but still below Eurasian perch (Percafluvatilis) of is $88-115 \mathrm{mM}$ (Kestemont, et al., 2015). This value is very low when compared to other types of saltwater fishes ofsalmon (Oncorhynchusmasou) containing chlorine of $130 \mathrm{mM}$ (Morisawa, et al., 1983). Finally, calcium ion content of fishes (Plecoglossusaltivelis) is $2.3 \mathrm{mM}$, within sea-water commodity and Eurasian perch (Percafluvatilis) of freshwater commodity of 1.7-2.8 mM (Morisawa et al. 1983; Kstemont et al., 2015). Differ with other other fishes, Tiger grouper contain up to $15.19 \mathrm{mM}$ calcium. Thesperm plasma contain $\mathrm{Ca}^{2+}$ ions, it relates to protein phosphorylation at base of sperm tail to trigger motility or movement (Dreanno, et al., 1999).

The FTIR examination in Table 3 shows that each test fishes sperm has nine color spectrum. Each color spectrum was matched by the Socrates guideline (1994) and obtained several types of compounds such as $\mathrm{OH}, \mathrm{CH}$ with stretch bonds, $\mathrm{C}=\mathrm{C}$ nonconjugated bonds, $\mathrm{CH}$ with covalent bonds, $-\mathrm{CO}$ with stretch bonds, $\mathrm{CO}$ alcohol and = $\mathrm{CH}$ cyclic bond. Patra (2010) said that the IR wave absorption data of $\beta$-sitosterol compounds is characterized by presence of alcohol groups in hydrogen vibration region with a frequency of $3549.99 \mathrm{~cm}^{-1}$, alkyl groups at frequency of $2935.73 \mathrm{~cm}^{-1}$ and $2867.38 \mathrm{~cm}^{-1}$ and an alkenyl group at a frequency of $1637.63 \mathrm{~cm}^{-1}$. Saeidnia, et. al. (2014) adds that in additionto above data there is also absorbs of ester-group IR waves for $\beta$-sitosterol at a lower frequency of $1063 \mathrm{~cm}^{-1}$. There is strong allegations that sperm of fishes grouperscontain steroids in form of $\beta$-sitosterol.

\section{ACKNOWLEDGEMENTS}

The authors are grateful to Maya, Komang Pull and Ahmad Muzaki for their help during preparation and the experiment. Moreover, the author would like to thank toanonymous reviewers who amply contributedto the improvement of this manuscript.

\section{REFERENCES}

Alavi, S.M.H., A.A.E. Butts, A. Hatef, M. Mommens, E.A. Triple, M.K. Litvak and I. Babiak, 2011. Sperm morphology, ATP content, and analysis of motility in Atlantik halibut (Hippoglossushippoglossus). Can. J. Zool., 89: 219-228.

Bunting, S.W., 2013. Principles of sustainable aquaculture.Earthscan from Routledge.2 Park Square, Milton Park, Abingdon Oxon, OX 14 4RN.Ebook. ISBN13: 978-0-203-12743-8, pp: 129-130.

Bozkurt, Y., F. Ogretmen, O. Kokcu and U. Ercin, 2011. Relationships between seminal plasma composition and sperm quality parameters of the Salmotruttamacrostigma(Dumeril, 1858) semen: with emphasis on sperm motility. Czech. J. Anim. Sci., 56(8): 355-364.

Cosson, J., A. Groison, M. Suquet, C. Fauvel, C. Dreanno and R. Billard, 2008. Marine fish spermatozoa: racing ephemeral swimmers. Review Reproduction, 136: $277-294$.

Dreanno, C., J. Cosson, M. Suquet, C. Cibert, C. Fauvel, G. Dorange and R. Billiard, 1999. Effect of osmolality, morphology perturbations and intracellular nucleotide content during the movement of sea bass (Dicentrarchuslabrax) spermatozoa. Journal of Reproduction and Fertility, 116: 113-125.

Hajirezaee, S., B.M. Amiri, A. Mirvaghefi and A.S. Ahmadi, 2010. Evaluation of semen quality of endangered Caspian brown trout (Salmotruttacaspius) in different times of spermiation during the spawning season. Czech J. Anim. Sci., 55(10): 445-455.

Jayadi, A. Mallawa, N. Nessa, I. Djawad and Ardiansyah, 2017. Growth patterns of camouflage grouper (Epinephelus plyphekadion, Bleeker, 1849) larvae. J. Fish. Aquat. Sci., 12(1): 12-21.

Kestemont, P., K. Dabrowski and R.C. Summerfelt, 2015. Biology and Culture afPercid Fishes. Springer Sciences Business Media Doedrecht. Ebook. ISBN. 978-94-017-7227-3, pp: 165-169.

Kim, S.H., C.H. Lee, Y.B. Song and Y.D. Lee, 2013. Ultrastructure of late spermatids and spermatozoa during spermiogenesis in longtooth grouper Epinephelus bruneus from jejeu, korea. Tissue and Cell, 45(4).

Mekkawy, I.A.A. and A.G.M. Osman, 2006. Ultrastructural studies of the morphological variations of the egg surface and envelopes of the African catfish Clariasgariepinus (Burchell, 1822) before and after fertilization, with a discussion of fertilization mechanism. Scientia Marina: pp: 23-40. ISSN:0214-8358.

Morisawa, M., K. Suzuki and S. Morisawa, 1983. Effects of potassium and osmolality on spermatozoan motility of salmonid fishes. J. Exp. Biol., 107: 105113.

Pahlevi, R.S., F.L. Tunxi and C.J. Ying (eds), 2016. Japanese Trust Fund V: Traceability systems for aquaculture products in the ASEAN region 2010-2015, pp: 19-28. ISBN 978-981-09-8684-1.

Palm, H.W., I. Yulianto, S. Theisen, S. Rueckert, S. Kleinnertz, 2015. Epinephelus fuscoguttatus mariculture in Indonesia: Implications from fish parasite infections. Regional Studies in Marine Sciences.doi.org:10.1016/j.rsma.2015.07.003.

Patra, A., S. Jha, P.N. Murthy, Manik and A. Sharone, 2010. Isolation and characterization of stigmast-5-en-3 $\beta$-ol ( $\beta$-sitosterol) from the leaves of Hygrphilaspinosa. International Journal of Pharma Sciences and Research, 1(2): 95-100.

Rurangwa, E., D.E. Kime, F. Ollevier and J.P. Nash, 2004. The measurement of sperm motility and factors affecting sperm quality in cultured fish. Aquaculture, 234: 1-28.

Schütze, S., 2015. DNA stability of stallion sperm: factors affecting chromatin integrity in individual stallions. Thesis.University of Veterinary Medicine Hannover, 83 .

Saeidnia, S., A. Manayi, A.R. Gohari and M. Abdollahi, 2014. The story of $\beta$-sitosterol - a review. European Journal of Medicinal Plants, 4(5): 590-609.

Sugama, K., 2014. Public policy for sustainable development of grouper aquaculture in Indonesia, pp: 1-8.

Suquet, M., R. Billard, J. Cusson, G. Dorange, L. Chauvaud, C. Mugnier and C. Fauvel, 1994. Sperm features in turbot (Scophthalmus maximus): a comparison with other freshwater and marine fish spesies. Aquat.Living.Resour, 7: 283-294.

Tian, Y., W. Qi, J. Jiang, N. Wang, D. Wang, J. Zhai, C. Chen and S. Chen, 2013. Sperm cryopreservation of sex-reversed seven-band grouper, Epinephelus spemtemfasciatus. Animal Report Science, 137: 230-236.

Tuset, V.M., E.A. Trippel and J. de Monserrat, 2008. Sperm morphology and its influence on swimming speed in Atlantic cod. J. Appl. Ichthyol., 24: 398405.

Verma, D.K., P. Routray, C. Dash, S. Dasgupta and J.K. Jena, 2009. Physical and biochemical characteristics of semen and ultrastructure of spermatozoa in six carp species. Turkish Journal of Fisheries and Aquatic Sciences, 9: 67-76.

Widyatmoko, H., 2004. Akurasi Wavelenght-disperse x-ray fluorescence. MakaraTeknologi, 8(2): 61-68.

Yulianto, I., C. Hammer, B. Wiryawan, H.W. Palm. 2015. Potential and risk of grouper (Epinephelus spp., Epinephelidae) stock enhancement in Indonesia. $J$ Coast Zone Manag.18: 394.doi:10.4172/2473-3350.1000394. 